\title{
E्己̌reAáo \\ Learning from and with the Education Movements in Greece and Brazil: knowledge, action and alternatives
}

\author{
Spyros Themelis \\ 'University of East Anglia (UEA), Norwich - United Kingdom
}

\begin{abstract}
Learning from and with the Education Movements in Greece and Brazil: knowledge, action and alternatives. The insights shared in this paper are based on research conducted in Greece and Brazil It is centered around the exploration of activist knowledge as a distinct form of knowledge. In doing this, it discusses the role of reflection in acquiring critical consciousness as well as the unified and holistic character of activist knowledge. This unity entails the intertwining of action with reflection and action with theory. It shows how critique forms a key feature of activist knowledge and highlights some nuances, tensions and contradictions inherent in the knowledge production of this kind. The latter is shown to be underpinned by plural dialogical processes, which further challenge and enrich knowledge produced in social movements. The paper aims to feedback insights from theory into praxis and vice versa. To achieve its aims, it approaches learning as an ongoing part of the quest for meaning and the quest of meaning as an integral part of acting.
\end{abstract}

Keywords: Activist Knowledge. Social Movements. Brazil. Greece. Education.

RESUMO - Aprendendo com e a partir dos Movimentos da Educação na Grécia e no Brasil: saberes, ação e alternativas. As ideias compartilhadas neste artigo são baseadas em uma pesquisa realizada na Grécia e no Brasil, e enfoca o exame dos saberes ativistas como uma forma distinta de saber. Ao fazê-lo, discute o papel da reflexão na aquisição da consciência crítica, bem como o caráter unificado e holístico dos saberes ativistas. Esta unidade implica o entrelaçamento da ação com a reflexão e da ação com a teoria. $\mathrm{O}$ artigo também mostra como a criticidade constitui um aspecto-chave dos saberes ativistas e destaca algumas nuances, tensões e contradições inerentes à produção deste tipo de saber, que é sustentado por processos dialógicos plurais que desafiam e enriquecem ainda mais os saberes produzidos em movimentos sociais. O artigo objetiva produzir ideias oriundas da teoria para a práxis e vice-versa. Para alcançar seus objetivos, considera a aprendizagem como parte continuada da busca de sentido, e a busca de sentido como parte do agir.

Palavras-chave: Saberes Ativistas. Movimentos Sociais. Brasil. Grécia. Educação.

Educação \& Realidade, Porto Alegre, v. 43, n. 3, p. 799-816, July/Sept. 2018.

799

http://dx.doi.org/10.1590/2175-623674796 
Learning from and with the Education Movements in Greece and Brazil

\section{Introduction: on activist knowledge and other types of knowledge}

Is there such a thing as activist knowledge? And, if there is, what does it consist of? How do we distinguish it from other, for example, non-activist types of knowledge? Like any other kind of knowledge, I contend that activist knowledge exists, but not independently from our ideas about it. In other words, we can talk about activist knowledge as a separate form of knowledge, as a distinct category of analysis, but we have to be aware that this is still part of a thought process. In other words, knowledge, activist or otherwise, does not stand independently from our ideas and, crucially, experiences of it. It is an heuristic devise, a useful one for that matter, which we utilise in order to elaborate on the categories of meaning and the meaning activists give to their practice as well as in order to conceptualise this practice and the knowledge it produces. However, activist knowledge, unlike many other types of knowledge, has a crucial difference. It is steeped in action. It could be argued that activist knowledge is in constant action itself: from thinking to acting, from acting to reflecting, from reflecting to knowing, from knowing to thinking and so on, ad infinitum. While this is a valid conceptualisation of the way activist knowledge is generated, I will return to this later. For the moment I would like to stress the fact that this chain of activist knowledge-production does not have a pre-ordained starting point. In other words, it could also take the form acting-thinking-reflecting-knowing-acting or the form knowing-acting-thinking-reflecting, and so on.

Most often, though, it starts from any of these states mentioned above, that is to say acting, thinking, or knowing, and it then leads to some reflection that informs further action. This reflection-informed action leads to new thinking, while this new thinking, in turn, leads to some fresh knowing, which further leads to some new acting and so on. However, the process of activist learning is not operated by cogs (i.e. acting, thinking, reflecting and knowing) that are set a priori or mechanistically related to each other. Acting, thinking, reflecting and knowing are all dynamically connected to each other and dialectically linked to existing action, thought, reflection and knowledge of the world they seek to change. In this vein, it is common for activist knowledge to produce not merely new thinking, acting or knowing, but thinking, acting and knowing that are qualitatively different from other novel ways of thinking, acting or knowing which are not associated with activism. In other words, activism often generates a re-thinking of the existing state of affairs (e.g. of the education system and relationships therewith) and it is enmeshed in acting that has the potential to lead to alternative ways of thinking about (doing) things as well as about doing things that would not be practicable to non-activists. The type of activism I discuss in this paper draws on the daily life, the cotidiano, of education activists in selected places in Greece and Brazil. In other words, it zooms in on the daily experiences and interactions of activists in their ordinary contexts. It does not follow them in exceptional, critical or moments of

800 Educação \& Realidade, Porto Alegre, v. 43, n. 3, p. 799-816, July/Sept. 2018. 
excess. Instead it reports on the routine of praxis, by gleaning instances of the daily in social movements ${ }^{1}$.

Despite the presentation of selected examples in relation to the movements I researched and interacted within each country, a systematic comparison between them is beyond the remit of this paper. This is to keep with the aims of the paper which do not involve to presentation of two case studies and their subsequent comparison. Rather, my intention is to use insights gained from the study of and interaction with diverse movements in Greece and Brazil in order to advance an analysis of activist knowledge and its tenets.

\section{Research Design}

Before I proceed to my analysis, it is important to introduce, though briefly, the research design and methods. The design and parametres of this research are reported elsewhere in some more detail (Themelis, 2017). Here, suffice to say that I employed live methods (Back and Puwar 2012; Simbuerger and Neary, 2015) in an overarching approach that holds implications with intervention sociology (Touraine, 1981). Regarding the findings reported here that relate to Greece, the main bulk of the material upon which they are based was collected over a number of visits conducted from 2010 to 2014 in various Greek cities and mainly in Athens. I conducted participant observations in various activist forums, events, meetings and activities, informal conversations with dozens of activists as well as semi-structured interviews with 18 academics and 11 secondary school teachers. The findings that relate to Brazil are based on material collected during a visit to Brazil in AugustSeptember 2015. There I visited three places, namely Rio de Janeiro, Limoeiro do Norte and Fortaleza, where I conducted participant observations and actively participated in various cultural, political, education and social meetings, gatherings and events, such as seminars, demonstrations, informal and formal meetings. Out of the plethora of events I partook, two are of particular importance with reference to the issues I discuss in this paper, namely the Forum of Social Movements in Rio de Janeiro and a gathering organised by the MST community in Limoeiro do Norte. Apart from informal discussions with several activists, academics and students in Brazil, I kept regular and extensive notes in my research diary, which furnished me with insights into some of the issues I discuss below. Although semi-structured interviews on cognate topics were conducted after the specific visit to Brazil, in this paper I reply only on material collected during this visit.

\section{What does Activist Knowledge Consist of?}

In first section 1, I noted that activist knowledge is a valid yet distinct form of knowledge. However, I have yet to delineate its distinct qualities, its unique features that allow us to demarcate it from other knowledges. Like any concept, category, word, action, process, experi- 
Learning from and with the Education Movements in Greece and Brazil

ence, idea and living product that evolves from activism, activist knowledge itself is part of a living process. Therefore, it is never static but constantly moving and changing. While this might justifiably form a key feature of activist knowledge, if we want to treat it as a separate analytic entity, we have to crystallise further its core components. But which might these components be? What follows ought to be approached not as a prescriptive list of ingredients that form a successful recipe. Rather, they have to be treated as some key features of a multifaceted and continuously changing process.

\section{Reflection for Acquiring Critical Consciousness}

As Freire (1985, p. 68) aptly put it “[...] only beings who can reflect upon the fact that they are determined are capable of freeing themselves. Their reflectiveness results not just in a vague and uncommitted awareness but in the exercise of a profoundly transforming action upon the determining reality". Reflection, therefore, is derived from and acquired with "[...] engagement and objective distance, [through] understanding reality as object, understanding the significance of men's actions upon objective reality, creative communication about the object by means of language, plurality of responses to a single challenge-these varied dimensions testify to the existence of critical reflection in men's relationships with the world" (Freire, 1985, p. 69). This relationship with the world is crucial in understanding how activist knowledge emerges and how it differs from other types of knowledge. In order to access it, people need to engage in a dual process that involves the objectification of the world as well as action to change it. This process forms part of what Freire (1985) calls critical consciousness which, for him, "[...] is never a mere reflection of but a reflection upon material reality" (Freire, 1985 , p. 69). In other words, critical consciousness does not provide people with an image of reality as a factual representation of the objective world. Rather, it furnishes them with the tools to think through it, to enquire about it and to contest and transform it. Critical consciousness, therefore, is brought about "[...] not through an intellectual effort alone, but through praxis- through the authentic union of action and reflection. Such reflective action cannot be denied to the people [...] Revolutionary leadership needs the people in order to make the revolutionary project a reality, but the people in the process must become more and more critically conscious" (Freire, 1985, p. 87).

It must have become evident that activist knowledge is not arrived at by reasoning alone, but by acting in a critical and reflective manner. This way of acquiring knowledge marks a departure from other ways given that it is formed through a process of living in the world, thinking in order to understand it and acting to change it. This process forms the triptych reflection-critical consciousness-action and has best to be approached as a symbiotic relationship among social movement activists.

But how exactly is reflection employed in the acquisition of critical consciousness? Reflection was used by education movement activ- 
ists in Greece in order to challenge the dominance of the textbook as the only source of knowledge, to push the boundaries of conventional school wisdom and re-configure the teacher-student relationship on a more respectful basis.

In this paper, I included findings from selected education movement activists I interviewed or spoke to, depending on their degree of introspection about the processes discussed in this paper. Maria, for example, whose excerpts from a group interview I discuss below, was one of 11 secondary school teachers I interviewed. Her location in the activist ensemble and struggle can be gleaned through the importance of reflection in the shaping of her consciousness.

Consistent with my focus in this section on reflection and critical consciousness, Maria, a secondary school teacher in an inner-urban school in Athens, offers unique insights into how this process was realised. The incident she recounted took place in a Year-10 class attended by some 30 students. The day of the incident was an important one as it coincided with one of the biggest strikes ever called by trade unions in austerity Greece. As Maria told me, she could sense that there was tension in the air as soon as she entered the classroom. Within a few minutes into the lesson, an articulate male student raised his voice to challenge the purpose of the session by stating: "I'd rather be on the street demonstrating right now rather than paying attention to useless stuff". Maria did not try to discipline the student nor did she try to abort the contamination of other students by this seemingly insolent remark. Instead, she used it as an opportunity to reflect on the socio-economic situation in Greece and the reasons that made people protest frequent$1 y^{2}$. And when another student extended the provocation to ask Maria why she was not joining the protesters, she reflected even deeper on what she perceived to be a state of depoliticisation and demoralisation that, to her, seemed to be widespread among her colleagues. Instead of shying away from it, she offered her reflection on this situation and asked her students about their own thoughts on it. Maria soon realised that most of her students' parents had either lost their jobs or were facing serious employment issues, ranging from underemployment to high redundancy risk. The discussion led to further reflection, this time, collectively, that is to say between Maria and the entire class. According to Maria “[...] there is no point trying to teach from the textbook when you know that what your students worry about is whether there will be any food on the table when they go home that afternoon or if the heating will be switched on at home that day". Reflections like this led to the enactment of critical consciousness through critique and reflection. Maria confessed that this incident made her question her role as a teacher and a human being, and reflect on her responsibilities towards her students and society. Reflection enabled her to identify a gap, as she called it: a silence that was a guilty one, you know, that kind of thing that goes "[...] someone else will do it for me"; well, I couldn't take it any more. By this, she meant that she started feeling the need to not only question but also to think. Thinking involved reading more about the crisis that had en-

Educação \& Realidade, Porto Alegre, v. 43, n. 3, p. 799-816, July/Sept. 2018. 
Learning from and with the Education Movements in Greece and Brazil

gulfed Greece and discussing it with colleagues and friends. One of the books that she and her activist colleagues had read was Naomi Klein's The shock doctrine. "It's all in there!", they all agreed. "All you need to know about crisis, Greece, neoliberalism and the world, is in that book", they explained. "Where was I living before reading that book?" asked Maria in bemusement. "I had no idea how the world was governed, what it was all about. I was going to my class, doing my job, going home and that was all about it. That book changed the way I think, who I am", she concluded. And that led naturally, without trying to force it, to [Maria] becoming interested. Talking to others about politics, asking questions, trying to understand what is going on at a higher level. I started asking the girls [points at her friends] about certain things, about the crisis, about everything that was going on. And together we started doing things, like going to demos, talking to the parents [of our students], all sorts of things. Becoming an activist, according to Maria, is the only way she can now understand and feel the world. In other words, she can only be in the world if she can be with it.

While many teachers I spoke to were sympathetic to activists and social movements in Greece and internationally, only a few of them took the extra steps required to become part of them. Both groups possessed critical thinking, though only the latter possessed critical consciousness. Those sympathetic to the Greek education movement, for example, liked the fact that there was some pressure put on the Greek government and the political elites. They found it reassuring that strikes and demonstrations occurred, though they were annoyed by their frequency and cynical about their potential to change things. For them learning was detached from acting and it was mediated by third parties, such as the media, friends and others who conveyed the activist reality to them. This type of learning is what I call learning from the movements, that is to say a second-hand type of learning that has the potential to lead to first-hand learning, learning with the movements. The distinction is as crucial as that made by Freire (1985) between being in and with the world. While this is discussed at some length in section 3 , suffice to note here that, as with being with the world, learning with the movements requires some level of conscientization, which is a cornerstone in perceiving the reality around us in order to actively change it.

In this chain of events, the role of reflection cannot be understated. I suggest we approach reflection as a means of acquiring critical consciousness and the key to the generation of possibilities. In other words, reflection is a generative term of praxis. Maria's reflection was attuned to her students' need to understand the reality around them and, on the specific occasion, necessitated the formation of a political relationship between teacher and students; a relationship that was characterised by honesty and was permeated by the quest to question, dialogue and, in the process, to expose one's own limitations. As Aronowitz $(2008$, p. 163) reminds us, "Freire emphasizes reflection, in which the student assimilates knowledge in accordance with his or her own needs, rather than rote learning; he is dedicated, like some elements of the progressive 
tradition, to helping the learner become a subject of his own education rather than an object of the system's educational agenda". It is the transformative potential, therefore, of reflection that makes it paramount in developing critical consciousness.

\section{Unity Between Action and Reflection}

Freire (1985, p. 100) argued that "[...] knowledge involves a constant unity between action and reflection upon reality". This means that when we engage in acts of knowing we do not merely absorb knowledge, but we actively add our own understanding to it, we are shaping it together with other forces in a specific context and in tandem with other agents. In other words, we add our own layer of interpretation to social reality. According to Freire (1985) words are related to the world that surrounds us and meaning is arrived to by making connections with our environment. This is a process in which all humans engage, otherwise we would be communicative islands, each one of us giving different meaning to the same words or using different words to discuss, explain and conceptualise the same notions. For example, liberty has to be conceived in similar terms by members of the same social group otherwise there would be some serious repercussions on our liberties. What is more, meaning in everyday life is made possible through our abiding by some linguistic, communicative and social principles. When we are in the classroom, for example, meaning is arrived to thanks to the concurrent operation of two principles. First, we all recognise each other's right to speak, what we call freedom of speech, even when we might not agree with what the other person has to say. Second, we all observe the same conditions that allow for the freedom of speech to be realised, for example, we all stay silent when someone else speaks. Both principles, freedom of speech and the safeguarding of the conditions for its realisation, create a common ground, a consensus, over the meaning-making process. However, consensus is not necessarily a progressive process as it allows for domination to be exercised and inequalities to operate. For example, liberal democracy is based on the principle of representation which many social movement activists perceive as a form of domination of the powerful political and economic interests against those of the vast majority of people. Consensus or to be more precise "engineered consensus" (Bernays, 1955), which is a pillar of parliamentary, majoritarian democracy, is seriously challenged by social movements and communities of activists. I contend that we approach this lack of adherence to normative frameworks that generate activist knowledge as a crucial difference between activist and other types of knowledge. This is not to say that activists do not abide by any rules or that they detest frameworks of common reference. Rather, it implies that the rules, norms and values that activists draw upon, more often than not, deviate from the majoritarian norms of liberal democratic organisation in some important ways. For example, while democracy is a core organisational principle it is also an axiological imperative for activists who reinterpret it in a way that seeks to improve existing operationalisations that have 
Learning from and with the Education Movements in Greece and Brazil

come to be accepted as natural, as if given by fiat, and are far removed from the spirit of democracy and the needs of the vast majority of the people in our societies. This interpretation of democracy serves as an example of how activist knowledge departs from mainstream, non-activist knowledges. This reinterpretation of notions, such as democracy, inescapably starts from critique which I discuss next.

\section{Critique}

As I eluded to above, activist knowledge is underpinned by a distinct approach to learning which is suffused with humanism. Critique is both a means towards the humanisation of society and a mode of being. What is more, I argue that in order to situate critique within current day activism, we need to strike a balance between critique against and critique for. I associate critique against, or negative critique, with approaches that are vested in negativity, a withdrawal from as Mouffe (2013) suggests. For some authors, this negative critique seeks to break with modernity and advance a new state of affairs. For Hardt and Negri (2000), for example, this is the altermodern, a form of life that moves beyond the shortcomings of modernity. For others, such as Virno (2004), the break with modernity entails a withdrawal from existing institutions which will allow for the development of the self-organisation of a revolutionary collective agent, the multitude (Hardt; Negri, 2005). However, there is another form of critique, which strives for engagement in order to achieve positive transformation. Mouffe (2013) for example, propounds the concept of engagement with institutions, such as democracy, in order to bring about a different type of hegemony than currently exists. This allows Mouffe (2013) to keep with the Gramscian idea of passive revolution or hegemony through neutralisation with which the creative potential of both capital and labour can be harnessed. I suggest that along these two competing conceptualisations of critique, we also consider critique for. Critique for seeks not only to dismantle and transform, but also to create. In so doing, it has the potential to become a liberating form of hegemony.

Education movement activists in Greece, for example, were indifferent to discussions about modernity and whatever lies beyond it. Rather, they were preoccupied with resisting austerity, critiquing the state, exposing the irrationality and brutality of capital, and uniting labour in contesting it. Their critique did not only stem from an interest to negate or transform the current state of affairs; it also had a desire to create an alternative, to explore new possibilities and ways of thinking about education, life, the economy, the environment, the media and so on. The difficulty, though, in social movements lies not in critiquing but in synthesising the different types of critique given the inherent diversity of opinions within them.

806 Educação \& Realidade, Porto Alegre, v. 43, n. 3, p. 799-816, July/Sept. 2018. 


\section{The Plural Dialogical Character of Activist Knowledge}

The pluralism within social movements is fascinating and, at the same time, challenging. Social movements I researched and participated in Brazil and Greece celebrate diversity of opinion and they encourage new, different and especially marginal voices to be heard. This, in turn, allows for a diversity of knowledge to emerge. In order to capture this diversity, it is important that we speak about activist knowledges rather than knowledge. However, we also need to be aware of a potential romanticisation of activist knowledge and any concomitant reification and fetishisation that might creep in. Those who work and live, act and think with social movements will be aware that, in some cases, not all voices and knowledges are equally heard and represented and that problems of representation and legitimacy abound. In other words, the world of activism is not immune from power differentials and issues of equity and equality (of participation, opportunity, representation and so on). Nevertheless, what distinguishes this world from that of mainstream politics is its increased awareness of these problems and its proactive attitude towards rectifying them. Through my own participation in activist meetings, forums, events and discussions both in Brazil and Greece, I witnessed more steps were taken in addressing some of these issues than in 10 years of experience in university and mainstream politics I had had from the mid-1990s to the mid-2000s. Notwithstanding the plurality and openness of activist voices, the contradictions embedded within activism and the impact of these contradictions on attendant knowledge production needs some further elaboration.

Consistent with the emphasis Freire (1970) put on dialogue in fostering critical consciousness, activist knowledge is shaped through constant and plural dialogue. That is to say, through a process that allows diverse voices to emerge and differences to be used as an opportunity rather than a threat. As I argued elsewhere (Themelis, 2016, p. 2).

[...] dialogue is a means of prefiguring new social rela-
tions that are democratic, direct and communicative, and
[aims] at the concientisation of fellow community mem-
bers. At the same time, dialogue is also part of a process
of transformation of the self, society and social relations.

The role of dialogue was evidenced in some observations I did with a community of activists near Limoeiro do Norte, North-East Brazil, in an area occupied by a $\mathrm{MST}^{3}$ community. While the living conditions of the community were rudimentary if judged in terms of amenities, such as electricity, running water, transport connections, access to products markets and so on, dialogue for them was an integral part of community organisation. In order to achieve this, space arrangements were configured in such a way as to promote the use of dialogue as a core component in the community's social relations. Specifically, a central, communal space in one of the very first huts of the settlement operated as the congregation hall, the place where members of the community would meet, discuss and decide about all significant matters. 
Learning from and with the Education Movements in Greece and Brazil

Suggestive about the importance of equality in their encounters, all chairs were arranged in a U shape, so that all participants could establish eye contact with each other and sitting arrangements would not give rise to power differentials ${ }^{4}$. Dialogue was in operation during my short stay there as visitors and locals formed a circle that allowed us to discuss issues about the education and social situation in Brazil and the UK. The knowledge that was thus produced was at one and the same time the product of all the participants and each one of us. Moreover, the process through which this was achieved was also part of a common framework that involved the co-creation, understanding of and reflection upon knowledge. While through dialogue we shared knowledge, we also produced a new meaning to notions such as community, equality, participation, democracy and so on. In this dialogical way, we practised the knowledge we produced and we transcended some sterile dichotomies, such as between thinking and acting; feeling and theorising; saying and doing. The debunking of these unproductive dualisms are further elucidated in the next section through the discussion of the way in which activists themselves understood their participation in social movements.

\section{Unity Between Action and Theory}

In considering the meaning and constituent elements of activist knowledge, I suggest we also approach it from the inside, that is to say from the point of view of activists themselves. In this way, an opening is made to the phenomenology of activist experience. Phenomenology is concerned with our perceptions of the lived world through the study of and reflection on structures of consciousness and the phenomena that we are able (and not able) to conceptualise. The activist phenomenology I am concerned with, while riddled with nuances and silences, it is rooted in a rejection of the dual conception of the world. What is more, it is interested in the abandonment of the dichotomy between external and internal world as distinct fields of experience. When education movement activists in Rio de Janeiro were discussing their involvement in university strikes, they never divided their experience between external and the internal. For them taking part in a counter-hegemonic activity was integral to a unifying experience of being in and with the world. At the same time, their being in the world did not contrast with their acting with it. Despite the contradictions in the daily life of activists and the diversity of experiences they conveyed, the experiences they discussed were organically tied to and symbiotically intertwined with their understanding of these experiences and the world around them. In this way, activists' understanding of their experiences resembled MerleauPonty's (1962) definition of phenomenology as embodied in experience. However, the activists' understanding of their own experiences moves beyond this level as they invariably also actively sought to unite acting with living, theory with practice and social justice with individual freedom. For want for a different term, I call this critical phenomenology.

808 Educação \& Realidade, Porto Alegre, v. 43, n. 3, p. 799-816, July/Sept. 2018 
This unity between external and internal, action and theory, is also extended to the way the world of activism represents discursively the action it is involved in. Hence, equally important to the shaping of critical consciousness of movement activists are the discourses produced about their experiences of acquiring such consciousness. Both in the MST communities in Brazil and in the activist groups I researched and worked with in Greece, the separation between discourse and practice was redundant. The need for the combination of a "[...] discourse of critique and resistance with a discourse of possibility and hope" (Giroux , 2008, p. 5) was contingent on the type of politics the activists were pursuing and the social relations that permeated their lives. The discursive aspect of activism I focus on relates to the type of knowledge produced by activists and the way this is communicated. Beyond reified notions of knowledge as they operate in traditional educational institutions where learning is equated with objective, static and measurable representations of reality as well as with transmission of knowledge from one learner's mind to another (Osberg; Biesta, 2007), activists' understanding of knowledge produced in and through their struggles was more in line with a pedagogy of possibility. This type of knowledge relates to the notion of emergence and it entails the creation of new properties (Osberg; Biesta, 2007). These properties "[...] have never existed before and, more importantly, are inconceivable from what has become before, are created or somehow come into being for the first time" (Osberg; Biesta, 2007, p. 33).

This form of knowing and knowledge constitutes a new way of learning and forms a new epistemological paradigm. Yet the idea is not new. Dewey (1963) highlighted long ago the importance of creating a school that is experienced as a series of little adventures that will improve both students and society, a school that allows students to reconstruct experience rather than instrumentally aggregate knowledge that will help them pass examinations and fit to the world of employment. Activists in the education movement in Greece wanted to abolish the sterile examination regime and replace rote learning with experiential learning. They did not want their students to regurgitate passively notions of equality and diversity; they wanted them to challenge existing ideas and form new categories of meaning; to reclaim meaning, even if this run against mainstream curriculum. They had at the heart of their efforts Arendt's (1961) question of whether we love the world and they approached learning as a political activity that seeks to construct the conditions for improving the world around them.

Similarly, activists in the education movement in Rio were not interested in creating a new methodology about teaching and learning, new textbooks that would replace the old ones; new managers that would be appointed in the place of existing ones. They were not motivated by a preoccupation with changing categories of meaning, to induce discursive or cosmetic changes to existing social categories. They drew inspiration on Freire who saw his work as a framework broad enough to incorporate all elements, discursive, representational, symbolic, inter-

Educação \& Realidade, Porto Alegre, v. 43, n. 3, p. 799-816, July/Sept. 2018. 
Learning from and with the Education Movements in Greece and Brazil

subjective and materialist alike. In other words, and this is a crucial point that needs highlighting, activist praxis for education activists in Rio was not relying on critical pedagogy as a means to an end. Critical pedagogy, for them, was a way of living. In that sense, it has to be approached as a philosophy rather than a method. This point is correctly emphasised by Aronowitz (2008, p. 162) who echoed Freire's intention to "[...] offer a system in which the locus of the learning process is shifted from the teacher to the student. And this shift only signifies an altered power relationship, not only in the classroom but in the broader social canvas as well". In a striking resemblance to the spirit of the Freirean philosophy, higher education activists in Rio de Janeiro sought to intervene to that social canvas as much as they sought to change education. The Forum of Social Movements I observed and participated in is a living application of Freire's anti-instrumentalism and all-encompassing philosophy.

\section{Dialectical and Class-Based Character}

As noted in the opening section, activist knowledge is premised upon dialectical underpinnings. In other words, it is riddled with contradictions but also possibilities. Freire (1985) invited us to approach knowledge as a process that starts from the effort to make meaning as members of social groups, to share an understanding with others that enables us to understand for ourselves: "[...] in epistemological terms, the object of knowledge isn't a term of knowledge for the knowing subject, but mediation of knowledge" (Freire, 1985, p. 100). This mediation consists of the transition to a new kind of thinking, which entails a transition to a new thought process. In turn, this has to be approached as a new framework for understanding the world rather than merely a new way of approaching knowledge. In a nutshell, it is the transition from the we think to the I think (Freire, 1985). Crucially, this shift from we think to I think indicates greater individual autonomy, a move away from herd-like attitudes to ones characterised by greater control over one's own life as well as by higher degree of critical reflection. Thinking which is not arrived at through obedience and compliance with a mass of individuals, but it is based on an embedded understanding of the thinker's role in his or her life. In other words, as Freire showed, this type of thinking entails a move away from fragmentation to collective learning and action. The $I$, therefore, is not subsumed, replaced or ignored by the we. Rather it is augmented and self-actualised through it. That is to say, the $I$ is located within the we rather than set against it, as, for example, is the case in our consumer-centered, individualistic societies.

An example from the struggle of teacher-activists in Greece might help me to illustrate this point further. As a result of the deepening economic crisis in Greece $^{5}$, malnutrition among pupils has been increasing owing to households' inability to make ends meet. In order to respond to this humanitarian crisis within Greek schools, teacher-activists

810 Educação \& Realidade, Porto Alegre, v. 43, n. 3, p. 799-816, July/Sept. 2018. 
would organise fundraising events with the support of the local community. For example, in some inner-city schools, the teachers organised flea market evenings on school premises in order to cover part of the nutritional needs of their students, a large number of whom was reported fainting or skipping classes owing to malnutrition.

This example shows that the response to poverty-induced challenges facing the students was the reinvention of the political and the re-appropriation of a small, though crucial part of everyday experience. Albeit limited in scope and insufficient to tackle the big problems, this and similar actions, can generate big waves towards the humanisation of everyday life. Instead of demanding the impossible or settling with the practical, for example politics as usual, activists intervened in order to reclaim the school as a space of possibility. Invariably, such actions are accompanied by similar ones, they are part of an ensemble of activities that trigger the political imagination of the community and unleash its creative potential. In many schools, parents would reciprocate the act of solidarity initiated by the teachers and a rapprochement of the school and the wider community would ensue. The outcomes achieved by such actions are not quantifiable, measurable in the traditional sense of the term that modern schools are accustomed to. By contrast, the quality of the schools thus produced is measured by the class solidarity it succeeds in establishing in the school (Freire, 1985), which can only be achieved through the democratisation of the school itself.

In another setting, the frequent interventions by teacher-activists in an inner city, urban primary school in Athens, were described by parents as acts of politicisation of a formerly apolitical mass. While the bigger politics was still the elephant in the room and the toll the economic crisis took on people's lives was spoken about vigorously, acts of humanisation such as the ones outlined above had a quadruple significance. First, they played a role towards the conceptualisation of schools as community spaces and their reclaiming as such. Second, they renewed politics inside the school and the community. Third, they offered a glimpse of an alternative way of self-organising beyond the dicta of school governmentality and centralised politics. And, fourth, they re-appropriated meaning lost both in endless a-signifying semiotics (e.g. visiting the school as part of a tacit, non-conscious-like activity, for example when dropping off one's kids; getting into contact with the school through meaningless acts dictated by the management style of the school rather than the need to communicate) and signifying semiotics (e.g. through the compliance to an uninteresting and outdated curriculum, which promotes conformity not enhancement of social value, it lacks in compassion, it treats knowledge-generation and acquisition as an instrumental task and so on) (Themelis, forthcoming).

\section{Discussion and Conclusions}

In the previous sections, I discussed the premises and constituent elements of activist knowledge. I did so from the vantage point of hav- 
Learning from and with the Education Movements in Greece and Brazil

ing learned from researching such movements as well as having learned through having interacted with and acted together with social movements. As stated in section Reflection for Acquiring Critical Consciousness, the first type of learning I call learning from the movements, while the latter learning with the movements. I propose we treat the distinction between learning from and with the movements as an extension of the distinction Freire (1985) made between being in and with the world. Freire forcefully argued about this distinction as a means of acquiring critical consciousness, which I argued is one of the key elements underlying the production of activist knowledge:

\begin{abstract}
Since the basic condition for conscientization is that its agent must be a subject (i.e. conscious being), conscientization, like education, is specifically and exclusively a human process. It is as conscious beings that men are not only in the world but with the world, together with other men [sic]. Only men, as 'open' beings, are able to achieve the complex operation of simultaneously transforming the world by their action and grasping and expressing the world's reality in their creative language (Freire, 1985, p. 68).
\end{abstract}

In other words, being human for Freire means becoming, fulfilling our role as conscious beings, which, in turn, is predicated upon two premises: pursuing actions that have the potential to transform life and reflecting upon these very actions. However, it needs to be stressed that these actions need to be critical, to have transformative potential, in order for conscientization to be acquired. Conscientization then is not merely another form of consciousness, but the process whereby people learn to "[...] perceive social, political, and economic contradictions, and to take action against the oppressive elements of reality" (Freire, 1985, p. 67). It is the process of developing a critical awareness of one's social reality through reflection and action. Action, in turn, is paramount because it is the process of transforming reality. In turn, transforming reality is a humanising process for our species. Not a separate activity reserved for the few, perhaps the professionals, such as politicians, but an essential part in the process of becoming. Changing reality then has to be approached not as the destination point, but as an ongoing process. However, knowing what to change requires more than immersion in the situation, being in the world (Freire, 1985). Crucially, it requires knowledge of the world as well as knowledge of one's own condition. In other words, if one wants to change the world they have to be with the world too:

[...] men can fulfill the necessary condition of being with the world because they are able to gain objective distance from it. Without this objectification, whereby man also objectifies himself, man would be limited to being in the world, lacking both self-knowledge and knowledge of the world (Freire, 1985, p. 68)

The type of activism I experienced in Greece and Brazil sits at an interesting crossroads. It lacks the messianic, all-change character 
of, say May 1968, but it is more pragmatic than that found in previous generations of activists. There were no grand statements of the kind be realistic, demand the impossible or no replastering, the structure is rotten. In the Greek case, activism, especially in the education movement, was pragmatic because it sought to embed the struggle in everyday life, in the right here, right now. As Amsler $(2015$, p. 19) suggests, the point of radical democratic thinking and acting is "[...] to weaken the attachment to practicality and replace it with an interest in the political; to make the impractical work of humanisation possible as part of the everyday experience of a liberating life, for all who desire it”.

In terms of activist knowledge, that is to say knowledge produced in praxis, it is important to note that this is "[...] not something that is made and finished once and for all. And consciousness is an intention towards the world [and] like our presence in the world, our consciousness transforms knowledge, acting about what enables us to reach the stage of reflection" (Freire, 1985, p. 100-101). In appraising the knowledge produced in social movements, I underscored the following characteristics. First, the role of reflection in acquiring critical consciousness. Instead of treating the latter as a variation of human consciousness, I discussed its qualitative differences with reference to activists in social movements in Brazil and Greece. In a nutshell, critical consciousness consists of reflection that leads to action. I then discussed how this action is in harmony with further reflection and the ways in which praxis unifies the concepts of action and refection into a coherent whole. The discussion involved an emphasis on the role of critique, because evidence from research I conducted in Greece and Brazil shows that critique runs across activist thought and praxis as well as the knowledge activists produce. In addition, activist engagement, I argued, is steeped in dialogical processes, which permeates social movements' operation. However, I underlined the nuances, contradictions and tensions in the workings of dialogue within social movements and I warned about a potential romanticisation and fetishisation of activist knowledge. These tensions are real, but the promise of activist knowledge lies in its quest for unity between theory and action. Instead, then, of sterile and defunct attempts to separate action from knowledge, social movements produce action-informed knowledge, while the freshly produced knowledge informs future action. Finally, I showed that this knowledge is qualitatively different from other types of knowledge in that it carries social class characteristics. Of course, all knowledge is the product of social classes trying to understand, interpret, classify and intervene in the world. Yet, the difference between activist and non-activist knowledge is that the former is consciously trying to intervene in the social relations through resistance, critique, dialogue and the proposal of alternatives.

But what is the significance of knowledge produced with and from social movements? I contend, its significance is fivefold. First, this type of knowledge and learning are important for the unity of the movement itself. Its importance for the movement is crucial because it makes despondency redundant and it fosters the nurturing of hope. Hope, in 
Learning from and with the Education Movements in Greece and Brazil

turn, becomes the architect of alternatives and the midwife of light. In terms of the societal importance of activist knowledge, it creates new representations, it produces a new social imagery and imaginary. While knowledge in itself cannot lead to a utopia, it is a necessary condition in the pursuit of liberation, freedom. And freedom is inescapably personal and social at the same time. The individual has to be liberated from the confines of oppression in order to be able to create a liberated society, while a liberated society can only function when all individuals are free.

Second, knowledge production that occurs outside the confines of existing institutional arrangements (e.g. schools, political parties or even outside state control) can become the vehicle of possibility for the movements themselves and for society as a whole. Third, learning from and with the movements is a premise of prefiguration. In other words, this type of knowledge is necessary in order to unlearn how we do things, to relearn how to do others and learn anew (for more on this, see Themelis, forthcoming). This learning and knowledge, though, is to be put into the service of humanity as a whole, rather than reserved for the intellectuals or the elites as is often the case with mainstream nonactivist knowledge.

Fourth, knowledge and learning from below are the catalysts for inter-movement collaborations (Santos, 2014). They can lead to possibilities for change and for sharing the benefits of this change widely. For the need to change is not limited to one area, city, nation or continent. It is a universal imperative if the human species is to survive: biologically, morally, spiritually and intellectually. This type of knowledge can lead to a short-circuit of the currently dominant knowledges and processes of knowledge production, which deprive humans from realising their collective potential and prevent them from utilising it to liberate themselves from the various forms of domination (epistemic, ideological, material, technological and so on). Finally, knowledge and learning with and from the movements are significant means for the "[...] revival of cultural and political traditions [as they seek to] mobilize people to address common concerns and issues through a process of organized, sustained, deliberate and informed activism" (Prasant; Kapoor, 2010, p. 208).

In this paper I discussed some key features of activist knowledge and underlined their importance through evidence from research I have been conducting with social movements in Greece and Brazil since 2010. While more insights and evidence are necessary in order to systematically discuss the characteristics of activist knowledge, I argue that this is also the time for more action. For, as I argued above, only knowledge that is in harmony with action is likely to produce the changes society needs. Social movements from below, then, have to be seen as the motors of a renewed way of thinking and acting towards changing the world as well as our expectations from, representations of, ideas about this world. In a nutshell, activist knowledge is as much about learning as it is about changing the way we think. And where case activist knowledge fails, it has to be acting we need to turn to, not merely thinking. 


\section{Notes}

1 My working definition of social movements is inspired by the Free Association (2011) which approaches them as experiments in excavating the power of capital and, as such, as key processes in the 'moving of social relations'.

2 In May 2010, Greece signed a memorandum of agreement with international lenders in exchange for harsh austerity measures. This sparked frequent and, in some cases, violent demonstrations and protests in almost every Greek city and chiefly in Athens. Only within the space of three months in the same year, five general strikes were called and protesters would take to the streets several times each week.

3 Movimento dos Trabalhadores Rurais Sem Terra (Movement of Landless Rural Workers or Landless People's Movement as it is widely known in the English speaking world).

4 This kind of spatial arrangements are by no means unique to this community. Many indigenous communities in Brazil also feature similar arrangements.

5 Within the first four years of the crisis (2009-2012), average household income dropped by $27 \%$ (Elstast, 2012) while the annual average rate of inflation was approximately $2,7 \%$ (www.inflation.eu). Children are disproportionally affected by drastic rises in inequalities and attendant loss of household income. Households for families with children lost in income the equivalent of 14 years of income progress as their income returned to 1998 levels (UNICEF, 2014). Consequently, child poverty sky-rocketed and Greece experienced the biggest percentage increase in child poverty and has the highest overall child poverty rate $(40 \%)$ (UNICEF, 2014)

\section{References}

AMSLER, Sarah. Education of Radical Democracy. London: Routledge, 2015.

ARENDT, Hannah. Between Past and Future: six exercises in political thought. New York: Viking Press, 1961.

ARONOWITZ, Stanley. Against Schooling: toward an education that matters. Abingdon: Routledge, 2008.

ELSTAST. Press Release. November 2, 2012.

BERNAYS, Edward. The Engineering of Consent. Norman: University of Oklahoma Press, 1955.

DEWEY, John. Experience and Education. New York: Collier Books, 1963 [1938]. FREIRE, Paulo. Pedagogy of the Oppressed. London: Penguin. 1970.

FREIRE, Paulo. The Politics of Education: culture, power, and liberation. South Hadley, Mass: Bergin \& Garvey, 1985.

GIROUX, Henry. Henry Giroux: rethinking the promise of critical education. Truthout, on-line, dez. 2008. Available at: <http://truth-out.org/archive/ component/k2/item/81318:henry-giroux-rethinking-the-promise-of-criticaleducation>. Accessed on: 6 abr. 2016 
Learning from and with the Education Movements in Greece and Brazil

HARDT, Michael; NEGRI, Antonio. Empire. Cambridge: Harvard University Press, 2000.

MERLEAU-PONTY, Maurice. Phenomenology of Perception. London: Routledge, 1962.

MOUFFE, Chantal. Agonistics: thinking the world politically. London: Verso, 2013.

OSBERG, Deborah; BIESTA, Gert. Beyond Presence: epistemological and pedagogical implications of 'strong' emergence. Interchange, Norwell, Kluwer Academic Publishers, v. 38, n. 1, p. 31-57, mar. 2007.

PRASANT, Kumar; KAPOOR, Dip. Learning and Knowledge Production in Dalit Social. Movements in Rural India. In: KAPOOR, Dip; CHOUDRY, Aziz (Org.). Learning from the Ground Up. New York: Palgrave Macmillan, 2010.

THEMELIS, Spyros. Dialogue and Praxis in the Pursuit of Utopia. In: VITTORIA, Paolo (Org.). Dialogo, Luogo Dell'utopia: Saggi, Proposte, Divergenze Dalla Pedagogia Critica. Traduzido por A. Lotti. Genova: Qunitadicopertina, 2016.

THEMELIS, Spyros. Learning, Unlearning, Relearning with the Movements: a study of an education movement and its prefigurative potential. Postcolonial Directions in Education, Msida, n. 6, v. 1, p. 28-53, 2017.

UNICEF. Press Release: 2.6 million more children plunged into poverty in rich countries during Great Recession. On-line: Unicef, oct. 28, 2014. Available at: <http://www.unicef.org/media/media_76447.html>. Accessed on: 6 abr. 2016.

VIRNO, Paolo. A Grammar of the Multitude. New York: Semiotext(e), 2004.

Spyros Themelis is a Senior Lecturer at the University of East Anglia. He is the author of the monograph Social Change and Education in Greece: a study in class struggle dynamics (2013, New York: Palgrave Macmillan) and various papers and high-profile reports on sociology of education, minority education and social inequalities. Since 2011, Spyros has been researching social and education movements and alternative (higher) education provision in Greece, Chile, Brazil and the UK. His recent and forthcoming publications evolve around this area.

E-mail: s.themelis@uea.ac.uk

This is an open-access article distributed under the terms of the Creative Commons Attribution License 4.0 International. Available at: <http://creativecommons.org/licenses/by/4.0>.

816 Educação \& Realidade, Porto Alegre, v. 43, n. 3, p. 799-816, July/Sept. 2018 